\title{
Protein Kinase C-Mediated Phosphorylation of a Single Serine Residue on the Rat Glial Glutamine Transporter SN1 Governs Its Membrane Trafficking
}

\author{
Lise Sofie H. Nissen-Meyer, Mark C. Popescu, El Hassan Hamdani, and Farrukh A. Chaudhry \\ The Biotechnology Centre and Centre for Molecular Biology and Neuroscience, University of Oslo, N-0317 Oslo, Norway
}

\begin{abstract}
Molecular mechanisms involved in the replenishment of the fast neurotransmitters glutamate and GABA are poorly understood. Glutamine sustains their generation. However, glutamine formation from the recycled transmitters is confined to glial processes and requires facilitators for its translocation across the glial and neuronal membranes. Indeed, glial processes are enriched with the system $\mathrm{N}$ transporter SN1 (Slc38a3), which, by bidirectional transport, maintains steady extracellular glutamine levels and thereby furnishes neurons with the primary precursor for fast neurotransmitters. We now demonstrate that $\mathrm{SN} 1$ is phosphorylated by protein kinase $\mathrm{C} \alpha$ $(\mathrm{PKC} \alpha)$ and $\mathrm{PKC} \gamma$. Electrophysiological characterization shows that phosphorylation reduces $V_{\max }$ dramatically, whereas no significant effects are seen on the $K_{\mathrm{m}}$. Phosphorylation occurs specifically at a single serine residue (S52) in the N-terminal rat (Rattus norvegicus) SN1 and results in sequestration of the protein into intracellular reservoirs. Prolonged activation of PKC results in partial degradation of $\mathrm{SN} 1$. These results provide the first demonstration of phosphorylation of SN1 and regulation of its activity at the plasma membrane. Interestingly, membrane trafficking of SN1 resembles that of the glutamate transporter GLT and the glutamate-aspartate transporter GLAST: it involves the same PKC isoforms and occurs in the same glial processes. This suggests that the glutamate/GABA-glutamine cycle may be modified at two key points by similar signaling events and unmasks a prominent role for PKC-dependent phosphorylation. Our data suggest that extracellular glutamine levels may be fine-tuned by dynamic regulation of glial SN1 activity, which may impact on transmitter generation, contribute to defining quantal size, and have profound effects on synaptic plasticity.
\end{abstract}

\section{Introduction}

The outcome of synaptic transmission depends to a large extent on the neurotransmitter released, the characteristics of the receptors activated, and the efficiency of the inactivation systems. Major advances have been made in the understanding of the dynamic regulation of neurotransmitter receptors and the pathophysiological roles of transporters that terminate neuronal signaling by removing the neurotransmitters from the synaptic cleft (Danbolt, 2001; Sorkin and Von Zastrow, 2002). However, molecular mechanisms involved in the replenishment of the fast neurotransmitters glutamate and GABA have eluded characterization.

Glutamine is the major precursor for glutamate and GABA (Battaglioli and Martin, 1990; Rothman et al., 2003). According to the prevailing hypothesis, a significant amount of released glu-

Received July 16, 2010; revised Feb. 4, 2011; accepted March 9, 2011.

Author contributions: L.S.H.N.-M. and F.A.C. designed research; L.S.H.N.-M., M.C.P., and E.H.H. performed research; L.S.H.N.-M., M.C.P., E.H.H., and F.A.C. analyzed data; L.S.H.N.-M., E.H.H., and F.A.C. wrote the paper.

This work was funded by The Norwegian Research Council (postdoctoral stipend, L.S.H.N.-M.; Young Outstanding Scientist Award, F.A.C.) and The Medical Student Research Program at the University of Oslo (M.C.P.). We are grateful to PhD student Laura Camassa for preparation of the primary rat astrocyte cultures and Gunnar Lothe for help with preparation of the figures.

Correspondence should be addressed to Farrukh A. Chaudhry, The Biotechnology Centre of 0slo and The Centre for Molecular Biology and Neuroscience, University of Oslo, P.0. Box 1125 Blindern, N-0317 0slo, Norway. E-mail: f.a.chaudhry@biotek.uio.no.

DOI:10.1523/JNEUROSCI.3694-10.2011

Copyright $\odot 2011$ the authors $\quad 0270-6474 / 11 / 316565-11 \$ 15.00 / 0$ tamate and GABA is transported into perisynaptic astroglial processes, converted to glutamine, and then transported back to neurons for transmitter regeneration (Albrecht et al., 2007). Existence of such a glutamate/GABA-glutamine cycle has been bolstered by the characterization of a family of system A and system N transporters: SAT1 (Slc38a1) and SAT2 (Slc38a2) are selectively enriched in GABAergic and glutamatergic neurons, respectively, and inhibition of system A transport inhibits neuronal transmitter generation and synaptic transmission (Bacci et al., 2002; Liang et al., 2006; Jenstad et al., 2009; Solbu et al., 2010). System N transporter SN1, selectively expressed on astroglial processes ensheathing synapses, mediates release of glutamine and furnishes neurons with the primary neurotransmitter precursor (Chaudhry et al., 1999, 2001; Boulland et al., 2002). Thus, functional integrity of SN1 may be a key regulator for the recycling of glutamate and GABA.

Classical biochemical experiments have demonstrated adaptive regulation of system A and $\mathrm{N}$ activities (Shotwell et al., 1983; Palacín et al., 1998). An amino acid response element regulating the promoter activity has been demonstrated for SAT2 (Palii et al., 2004), whereas a pH responsive element that has been identified in the $3^{\prime}$ untranslated region of SN1 increases protein expression during acidosis (Solbu et al., 2005). However, reports showing pronounced effects on $V_{\max }$ without changing $K_{\mathrm{m}}$ for the system $\mathrm{A}$ and/or $\mathrm{N}$ activities indicate recruitment of transporters from preexisting intracellular pools (Gebhardt and Kleemann, 1987; Hundal et al., 1987; Lohmann et al., 1998; Ling et al., 
2001; Pastor-Anglada et al., 2005). Membrane trafficking constitutes a major regulatory pathway for many transporters, including transporters for dopamine, serotonin, GABA, and glutamate, and is often governed by phosphorylation/dephosphorylation of specific residues on the transporter proteins (for review, see Robinson, 2002; Melikian, 2004). We therefore hypothesized that activity and/or subcellular localization of SN1 may also be regulated by phosphorylation and have functional implications. Using a multidisciplinary approach, including quantitative Western blotting, phosphopeptide mapping, confocal laser scanning microscopy, and electrophysiology, we demonstrate that rat $\mathrm{SN} 1$ is selectively phosphorylated at S52 by protein kinase $\mathrm{C} \alpha(\mathrm{PKC} \alpha)$ and PKC $\gamma$. Moreover, our data suggest that phosphorylation of SN1 stimulates retrieval of the protein from the cell membranes to intracellular reservoirs leading to reduced $V_{\text {max }}$, whereas $K_{\mathrm{m}}$ remains unaffected. Finally, we show that prolonged stimulation of PKC with phorbol ester leads to degradation of SN1. Altogether, our data suggest that SN1 activity is regulated by PKCmediated membrane trafficking and that it represents a key step in the regulation of transmitter replenishment and quantal size in the CNS.

\section{Materials and Methods}

Antibodies. Antibodies were generated in two rabbits against a glutathione $S$-transferase (GST) fusion protein containing the N-terminal of rat SN1 (N-SN1-GST). One antibody has been extensively characterized in previous reports (Boulland et al., 2002, 2003; Solbu et al., 2005). In the current study, both gave identical results on Western blotting (0.1-0.5 $\mu \mathrm{g} / \mathrm{ml})$ and immunocytochemistry $(1 \mu \mathrm{g} / \mathrm{ml})$. Two additional rabbits were immunized with keyhole limpet hemocyanin (KLH)-conjugated peptides corresponding to rat $\mathrm{SN} 1$ peptide sequence $46-58$, phosphorylated at S52 (21st Century Biochemicals). The obtained sera were run through a column containing KLH-conjugated unphosphorylated peptide, followed by affinity purification on a column containing the phosphorylated peptide. These phospho-specific antibodies were used at a concentration of $2 \mu \mathrm{g} / \mathrm{ml}$. Commercial antibodies were obtained against actin (1:2000; MAB1501R; Millipore Bioscience Research Reagents) and syntaxin 6 (1:200; 610635; BD Biosciences). Secondary antibodies used were ImmunoPure peroxidase-conjugated goat anti-rabbit $\operatorname{IgG}(1$ : 50,000; Pierce), goat anti-mouse IgG (1:100,000; Pierce), and goat antirabbit IgG and donkey anti-mouse IgG coupled to Alexa Fluor 488 and 555 (1:1000; Invitrogen), respectively.

Animal handling. The animals (male Wistar rats and Xenopus laevis) were kept and handled according to European regulations and under veterinary supervision at the animal facility [Institute of Basic Medical Sciences (rats) and Department of Molecular Biosciences (Xenopus), University of Oslo].

Cell cultures. $\mathrm{Na}^{+} / \mathrm{H}^{+}$exchanger-deficient PS120 cells derived from the hamster lung fibroblast line CCL-39, stably transfected with SN1 and characterized in previous reports (Chaudhry et al., 1999, 2002b), were grown in DMEM with GlutaMAX (Invitrogen) supplemented with 5\% fetal bovine serum (FBS), $1 \%$ penicillin/streptomycin, and $100 \mu \mathrm{g} / \mathrm{ml} \mathrm{Geneticin} \mathrm{(Invit-}$ rogen). COS-7 cells (CRL-1651; American Type Culture Collection) were grown in DMEM/GlutaMAX supplemented with penicillin/streptomycin and $10 \%$ FBS and transiently transfected with pCDNA3.1(+)-SN1 with Lipofectamine 2000 (Invitrogen) following the instructions of the manufacturer. Primary astrocytes were prepared from 1-d-old rat pups as described (McCarthy and de Vellis, 1980).

Phorbol-12-myristate-13-acetate treatment of cells. Cells, either transiently or stably expressing SN1, were either stimulated with $1 \mu \mathrm{M}$ phorbol-12-myristate-13-acetate (PMA) (1 $\mu \mathrm{M}$; P8139; Sigma) in dimethylsulfoxide (DMSO) (Sigma) or treated with the same volume DMSO as vehicle. The inhibitors bisindolylmaleimide I hydrochloride (Bis I) (B6292; Sigma) or staurosporine (S4400; Sigma) (both in $100 \mathrm{~nm}$ final concentration) were applied 15-30 min before PMA.

In vitro phosphorylation. N-SN1-GST fusion protein bound to glutathione Sepharose was phosphorylated in the presence of the catalytic

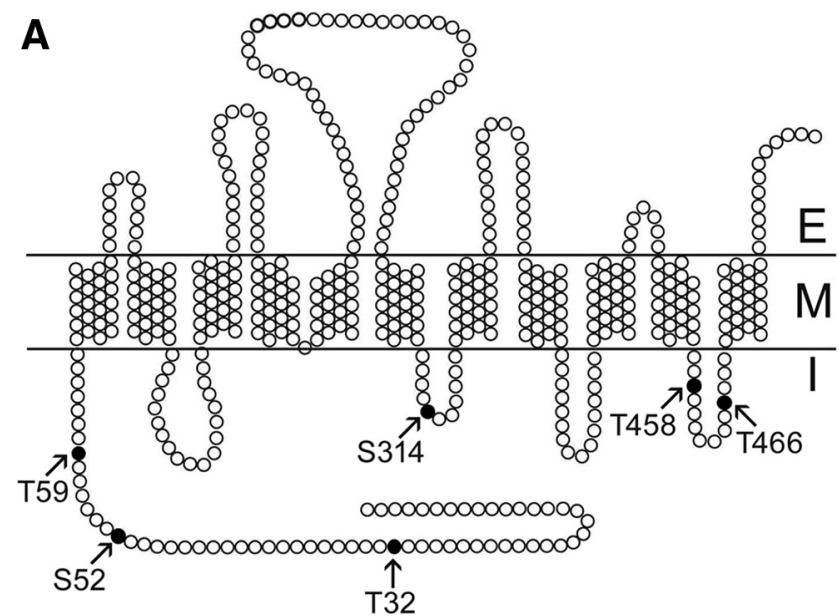

B

R. norvegicus
O. aries
M. musculus
H. sapiens
P. troglodytes
M. mulatta
E. caballus
S. scrofa
A. melanoleuca
B. taurus
C. lupus
O. cuniculus

Figure 1. Bioinformatical analyses of SN1 amino acid sequence identify several putative phosphorylation sites. $A$, The protein sequence of rat SN1 was analyzed by the computer-based program PROSITE, which identifies residues and motifs with a potential for phosphorylation by the most common characterized protein kinases. Applying the suggested topology model for SN1 (Chaudhry et al., 1999), several phosphorylation sites are located in the N terminus and intracellular loops. There are five putative phosphorylation sites for PKC (T32, S52, S314, T458, and T466) and three for CKII (S52, T59, and T458). B, The amino acid sequence of rat SN1 between residues 40 and 62 was aligned with several vertebrate orthologs, including human and mouse SN1. Note that the rat and sheep sequences have a triple serine at positions 51-53. All other vertebrates have a conserved proline corresponding to position 52. E, Extracellular; $\mathrm{M}$, membrane; I, intracellular; R. norvegicus, Rattus norvegicus (rat); 0. aries, Ovis aries (sheep); $M$. musculus, Mus musculus (mouse); H. sapiens, Homo sapiens (human); P. troglodytes, Pan trogIodytes (chimpanzee); M. mulatta, Macaca mulatta (Rhesus monkey); E. caballus, Equus caballus (horse); S. scrofa, Sus scrofa (domestic pig); A. melanoleuca, Ailuropoda melanoleuca (giant panda); B. taurus, Bos taurus (cattle); C. lupus, Canis lupus (dog); 0. cuniculus, Oryctolagus cuniculus (rabbit).

subunit of PKC $(0.1 \mu \mathrm{g} / \mathrm{ml})$ from rat brain (PKC-M; catalog \#539513; Calbiochem) at $30^{\circ} \mathrm{C}$ in $20 \mathrm{~mm}$ Tris- $\mathrm{HCl}, \mathrm{pH} 7.4,10 \mathrm{~mm} \mathrm{MgCl}_{2}, 1 \mathrm{~mm}$ EGTA, phosphatase inhibitors [6 mM p-nitrophenylphosphate, $12 \mathrm{~mm}$ $\beta$-glycerophosphate, and $0.02 \mathrm{~mm}$ sodium vanadate (Sigma)], and $[\gamma$ $\left.{ }^{32} \mathrm{P}\right]$ ATP (final concentration $0.2 \mathrm{~mm}, 12.5-20 \mu \mathrm{Ci} / \mathrm{ml}$; PerkinElmer Life and Analytical Sciences). Phosphorylation with human recombinant casein kinase II (CKII) (4-5 U/ $\mu$ l; Calbiochem) was performed in the same buffer with $50 \mathrm{~mm} \mathrm{KCl}$ added. Incubation (15 min) was stopped by washing in $40 \mathrm{~mm}$ EDTA in PBS with phosphatase inhibitors, before glutathione elution buffer was used for $10 \mathrm{~min}$ at room temperature (RT). Eluted protein was separated by SDS-PAGE. Phosphoproteins were visualized by autoradiography, and bands of interest were subjected to phosphopeptide mapping as described previously (Haug et al., 1999). No significant phosphorylation of GST (Rodriguez et al., 2005) was detected.

For phosphorylation of N-SN1-GST fusion proteins using the PKC Isozyme Panel (P6862; Sigma), the protocol of the manufacturer was followed and modified as necessary for glutathione Sepharose-bound protein. Incubations were performed for $10 \mathrm{~min}$. Phosphorylation with 

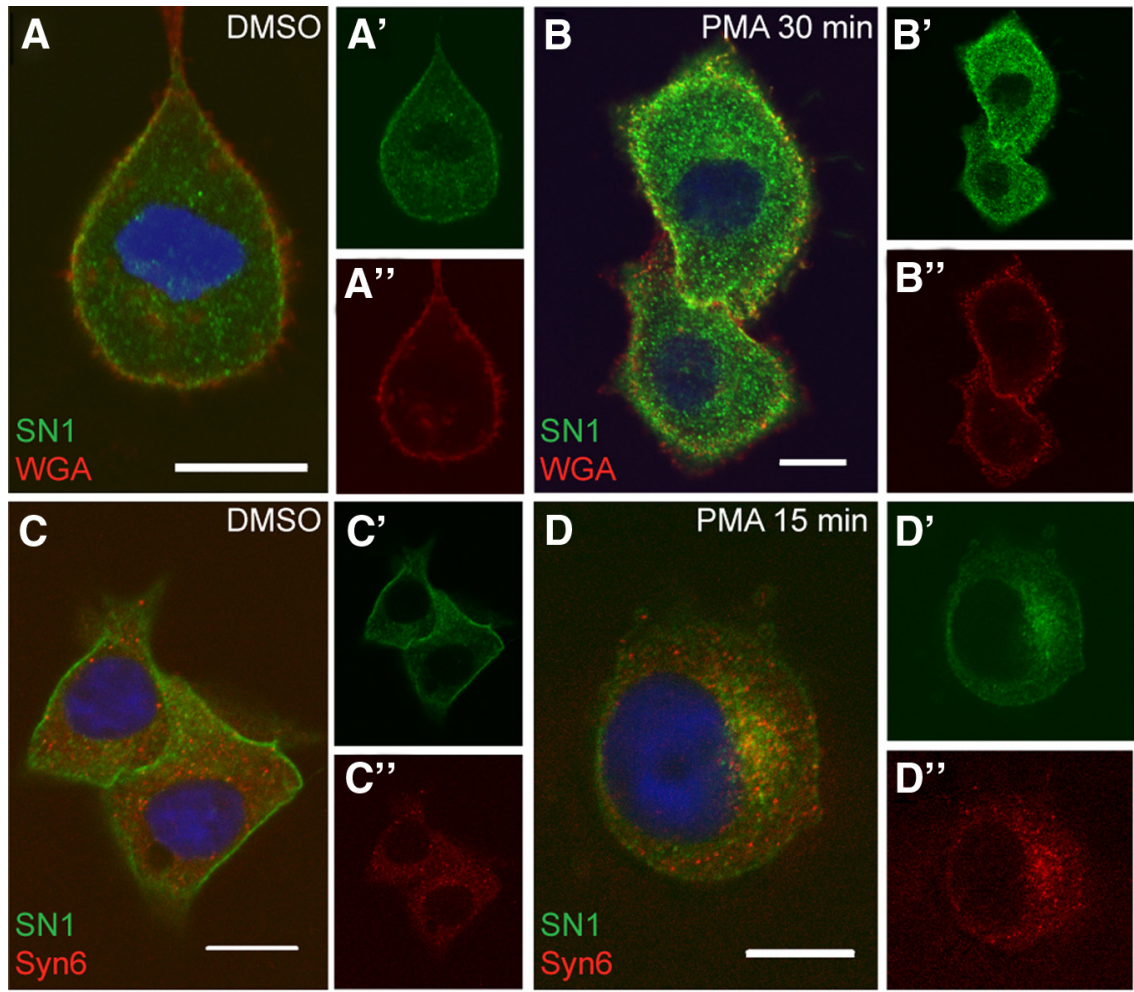

$\mathbf{E}$
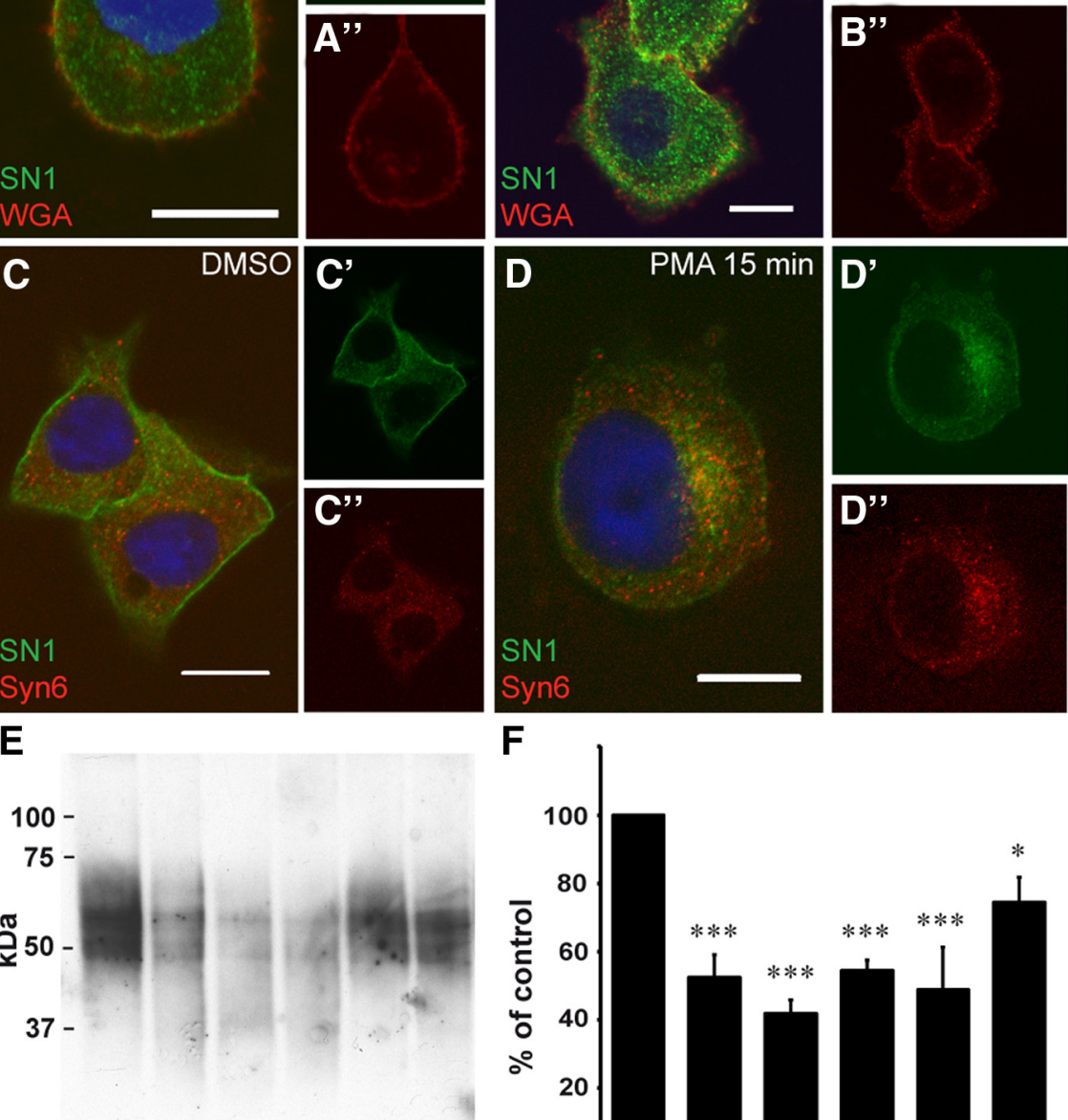

PMA: $\quad-\quad \begin{array}{llllll}0.5 & 1 & 2 & 0.5 & 2 & (\mathrm{~h})\end{array}$ Bis I: - $\quad-\quad-\quad+\quad+\quad+$ $\mathbf{F}$

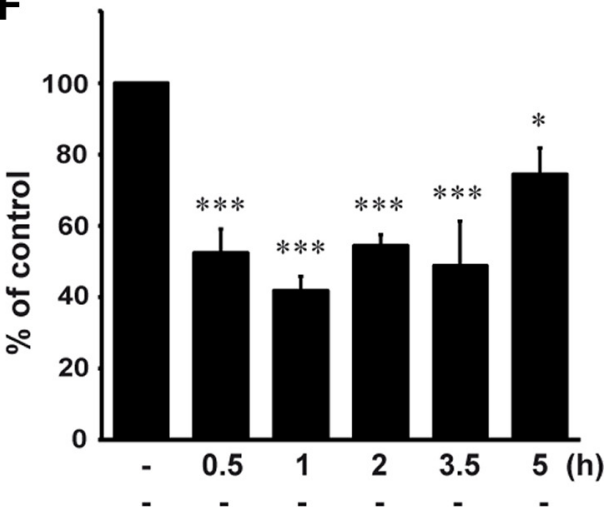

Figure 2. PMA-induced phosphorylation of SN1 results in internalization of the protein. A-D, PS120 cells stably transfected with SN1 were coimmunostained for SN1 and cellular markers. In the absence of PMA, pronounced immunostaining for SN1 occurs at the cell membranes $\left(\boldsymbol{A}^{\prime}\right)$ in which it is colocalized with WGA $\left(\boldsymbol{A}, \boldsymbol{A}^{\prime \prime}\right)$. During incubation of SN1 PS120 cells with $1 \mu \mathrm{M}$ PMA for 30 min, immunostaining for SN1 accumulates inside the cells $\left(\boldsymbol{B}^{\prime}\right)$, whereas colabeling with WGA $\left(\boldsymbol{B}, \boldsymbol{B}^{\prime \prime}\right)$ at the plasma membrane is attenuated. $\boldsymbol{C}$, Control cells immunostained for SN1 ( $\left.\boldsymbol{C}^{\prime}\right)$ and syntaxin 6 ( $\left.\boldsymbol{C}^{\prime \prime}\right)$ show no colocalization. $\boldsymbol{D}$, After PMA stimulation for 15 min, intracellular immunostaining for SN1 appears pronounced in the perinuclear region $\left(\boldsymbol{D}^{\prime}\right)$ in which it partly colocalizes with syntaxin $6\left(\boldsymbol{D}, \boldsymbol{D}^{\prime}\right) . \boldsymbol{E}, \boldsymbol{F}$, SN1 PS120 cells underwent stimulation with PMA $(1 \mu \mathrm{M})$ with or without inhibition by Bis I (100 nM) for different time intervals, followed by biotinylation of surface proteins. After avidin pull-down, biotinylated membrane proteins were subjected to SDS-PAGE and immunoblotted for SN1. PMA stimulation reduces SN1 staining of the plasma membrane proteins, whereas such reduction is abolished during coapplication of Bis I (E). $\boldsymbol{F}$, Quantification of SN1 immunoreactivity on plasma membrane fractions shows significant reduction from 0.5 to $3.5 \mathrm{~h}$ of PMA stimulation. Some of the SN1 immunoreactivity is restored after $5 \mathrm{~h}$. The error bars show \pm SEM of results from three to six experiments. ${ }^{*} p<0.05,{ }^{* * *} p<0.001$, when analyzed with SPSS (mixed models). Syn6, Syntaxin 6. Scale bar, $10 \mu \mathrm{m}$.

the classical PKC isoforms was performed in the presence of $200 \mu \mathrm{g} / \mathrm{ml}$ phosphatidylserine (P6641; Sigma) and $20 \mu \mathrm{g} / \mathrm{ml}$ diacylglycerol (D0138; Sigma). Activity of exogenous PKC enzyme was controlled by phosphorylation of Histone H1 (H4524; Sigma) in parallel samples.

Cellular phosphorylation followed by immunoprecipitation and phosphopeptide mapping. Transiently transfected COS-7 cells or stably transfected PS120 cells were preincubated $2-3 \mathrm{~h}$ in phosphate-free DMEM/ FBS and then incubated for $90 \mathrm{~min}$ at $37^{\circ} \mathrm{C}$ in $\left[{ }^{32} \mathrm{P}\right]$ orthophosphate $(1$ $\mathrm{mCi} / \mathrm{ml}$ in phosphate-free DMEM/FBS) in the presence of $0.45 \mu \mathrm{M}$ okadaic acid (O9381; Sigma). PMA (or DMSO) at $1 \mu \mathrm{M}$ was added for $30 \mathrm{~min}$ before the cells were washed twice with Trisbuffered saline (TBS) and lysed in $350 \mu \mathrm{l}$ of radioimmunoprecipitation assay (RIPA) buffer (150 mм NaCl, 50 mm Tris-Cl, pH 7.4, 1\% Triton X-100, $0.5 \%$ Na-deoxycholate, and $0.1 \%$ SDS) with Complete Protease Inhibitor Cocktail (Roche), 1 mm phenylmethylsulphonyl fluoride, and phosphatase inhibitors (see above). Homogenization and centrifugation for $5 \mathrm{~min}$ at 13,000 rpm was followed by immunopurification of lysates using Dynabeads Protein A (Invitrogen) (coupled with anti-SN1 and cross-linked following the protocol of the manufacturer) for $1 \mathrm{~h}$ at $4^{\circ} \mathrm{C}$ on a roller. After three washes with TBS-Tween $20(0.1 \%)$, SN1 was eluted with $0.1 \mathrm{M}$ citrate buffer, $\mathrm{pH} 3.0$, for $2 \mathrm{~min}$. SDS sample buffer was added, and the eluates were boiled and run on SDS-PAGE. Gels were stained in Coomassie blue (Sigma), destained, and dried in a Hoefer Slab Gel Dryer. Incorporated radioactivity was analyzed in a Typhoon 9210 Imager using ImageQuant 5.1 software (Molecular Dynamics). Guided by the autoradiogram, the radioactive spot was cut out of the gel, rehydrated in 50\% methanol, and subjected to phosphopeptide mapping as described (Haug et al., 1999).

Biotinylation and pull-down of membrane proteins. After stimulation with PMA and inhibitors, cell surface proteins were biotinylated with $0.5 \mathrm{mg} / \mathrm{ml}$ EZ-Link Sulfo-NHS-LC-Biotin (Pierce) in PBS (with $0.1 \mathrm{~mm} \mathrm{CaCl}_{2}$ and $0.1 \mathrm{~mm}$ $\mathrm{MgCl}_{2}$ ), pH 8.0, for $30 \mathrm{~min}$ at $4^{\circ} \mathrm{C}$ with gentle rocking (O'Shea et al., 2006). Excess biotin was quenched by washing three times in $100 \mathrm{~mm}$ glycin in PBS, after which the cells were lysed in RIPA buffer with Complete Protease Inhibitor Cocktail (Roche). Aliquots of lysates were subjected to protein measurement using the Bio-Rad protein assay kit with bovine serum albumin (BSA) as standards in an Envision 2102 Multilabel reader (PerkinElmer Life and Analytical Sciences) at $595 \mathrm{~nm}$. Avidin pull-down of the biotinylated plasma membrane proteins was performed using NeutrAvidin Agarose Resin (Thermo Fisher Scientific). The fraction of proteins not pulled down by NeutrAvidin is referred to as "intracellular" proteins. Plasma membrane and intracellular proteins equivalent to the lysate protein amounts were subjected to SDS-PAGE and immunoblotting following standard procedures (Boulland et al., 2004). The blots were blocked in 5\% fat-free milk and incubated overnight with antibody at $4^{\circ} \mathrm{C}$. After the washing steps, the blots were incubated with horseradish peroxidase-coupled secondary antibodies, and the immunoreaction was developed with SuperSignal West Pico Chemiluminescent Substrate (Pierce). Quantification was performed with a Typhoon scanner and ImageQuant software or, alternatively, with CL-Xposure films (Thermo Fisher Scientific) scanned in an Epson 4990 scanner and quantified with Adobe Photoshop CS4 (Adobe Systems).

Mutagenesis. Point mutations to the putative phosphorylation sites were introduced using the QuikChange site-directed mutagenesis kit (Stratagene) according to the instructions of the manufacturer and with primers designed with the QuikChange Primer Design program. All mutations were confirmed by sequencing of the clones.

Immunofluorescence. SN1-expressing PS120 or COS-7 cells and primary astrocytes were incubated with PMA with or without inhibitors for 
the times indicated. The cells were fixed for $30 \mathrm{~min}$ with 4\% paraformaldehyde (PFA) in PBS. When there was a need to stain plasma membranes, the fixed cells were incubated for $10 \mathrm{~min}$ in $5 \mu \mathrm{g} / \mathrm{ml}$ wheat germ agglutinin (WGA)-Alexa Fluor 555 conjugate (Invitrogen), following the protocol of the manufacturer. All cells were permeabilized and blocked at RT for 30-60 min in PBS containing 10\% FBS, 1\% BSA, and $0.5 \%$ Tween 20 . Primary antibodies were diluted in the same buffer, but containing $1 \% \mathrm{FBS}$, and incubated for $1 \mathrm{~h}$. After washing in PBS, the cells were incubated with Alexa Fluor 488 goat anti-rabbit IgG or Alexa Fluor 555 donkey anti-mouse IgG (1:1000; Invitrogen) for $1 \mathrm{~h}$ at RT. For double staining with two rabbit antibodies, the cells were incubated with preimmune IgG from rabbit (Jackson ImmunoResearch), followed by AffiniPure Fab Fragment goat anti-rabbit IgG and fixation with 4\% PFA to block the first primary and secondary antibodies, before incubation with the second primary and secondary antibodies (Boulland et al., 2004). The coverslips were mounted in Fluoromount-G (Southern Biotechnology) with 4,6'-diamidino-2-phenylindole (DAPI) (1:5000; Sigma). Antibody staining was visualized with a confocal laser microscope and corresponding software (LSM 510; Carl Zeiss).

Expression of SN1 in oocytes. RNA synthesis, transcription, and injection into $X$. laevis oocytes and investigation of glutamine transport using twoelectrode voltage clamp (TECV) were performed as described (Chaudhry et al., 2002b) using the oocyte clamp amplifier OC-725C (Warner Instruments). Oocytes were injected with $5-15 \mathrm{ng}$ of cRNA and incubated at $16^{\circ} \mathrm{C}$ for 5-10 d. Current and voltage pipettes were backfilled with $3 \mathrm{M} \mathrm{KCl}$ and had a resistance between 1 and $2 \mathrm{M} \Omega$. For studies involving current-voltage relationships, short voltage jumps were applied in increments of $20 \mathrm{mV}$ (range, -140 to $+40 \mathrm{mV}$; holding potential, $-40 \mathrm{mV}$ ). Currents recorded in the absence of substrate were subtracted from those in the presence of substrate.

Quantification and statistical analyses. Quantification of integrated optical density from blots was further analyzed using Microsoft Office Excel 2003, GraphPad Prism 5, and SPSS 18.0, using a linear mixed model analysis, with incubation time as the fixed variable and experimental batch a random variable. Figures were prepared using Adobe PhotoShop and InDesign CS4.

\section{Results}

PMA-mediated activation of PKC induces internalization of SN1

A topology model of SN1, based on hydrophobicity analyses, has been proposed (Chaudhry et al., 1999) to contain 11 transmembrane domains with an intracellular $\mathrm{N}$ terminal and several intracellular loops freely accessible for cellular kinases. PROSITE (ExPASy Proteomics Server), a Webbased primary protein sequence analysis program, was applied to search for motifs highly likely to be phosphorylated by common protein kinases. The long $\mathrm{N}$ terminus of rat $\mathrm{SN} 1$ is potentially phosphorylated by both PKC and CKII (Fig. 1A). Threonine 32 (T32) is a specific PKC target, whereas T59 has the properties of a CKII target. S52, which is surrounded by serines on both sides (Fig. $1 B$ ), may be targeted by both PKC and CKII. Furthermore, the distal intracellular loops also contain potentially phosphorylated residues: S314 and T466 are putatively phosphorylated by PKC, whereas T458 is a possible phosphorylation residue for both PKC and CKII (Fig. 1A). Analyses by PhosphoMotif Finder (Human Protein Reference Database) revealed some more potential phosphorylation sites but also pointed to S52 of rat SN1 as a putative PKC phosphor-
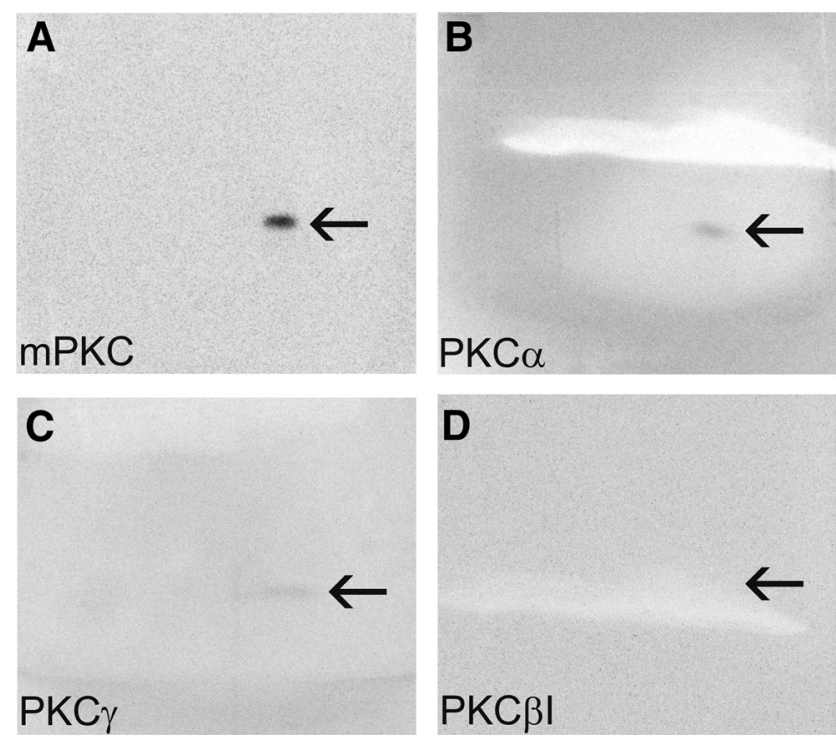

Figure 3. $\mathrm{PKC} \alpha$ and $\mathrm{PKC} \gamma$ phosphorylate the $\mathrm{N}$-terminal part of $\mathrm{SN} 1$ in vitro. Recombinant $\mathrm{N}$-terminal SN1-GST fusion protein bound to glutathione Sepharose underwent phosphorylation in vitro with $\left[\gamma^{-32}{ }^{32}\right] A T P$ and PKC-M (catalytic subunit from rat brain) or three recombinant PKC isoforms. After washing of the beads, elution, and SDS-PAGE to purify the fusion protein, the corresponding radioactive bands (localized by phospho-imaging) were cut out of the gel and subjected to thermolysin proteolysis, and phosphopeptides were applied to thin-layer silica sheets and analyzed by horizontal electrophoresis and vertical chromatography (phosphopeptide mapping). $\boldsymbol{A}-\boldsymbol{C}$, A single phosphopeptide (indicated by arrows) is detected at the same spot during stimulation with PKC-M (A), PKC $\alpha(\boldsymbol{B})$, and PKC $\gamma(\boldsymbol{C})$. D, PKC $\beta 1$ does not phosphorylate the N terminal of SN1 (arrow).
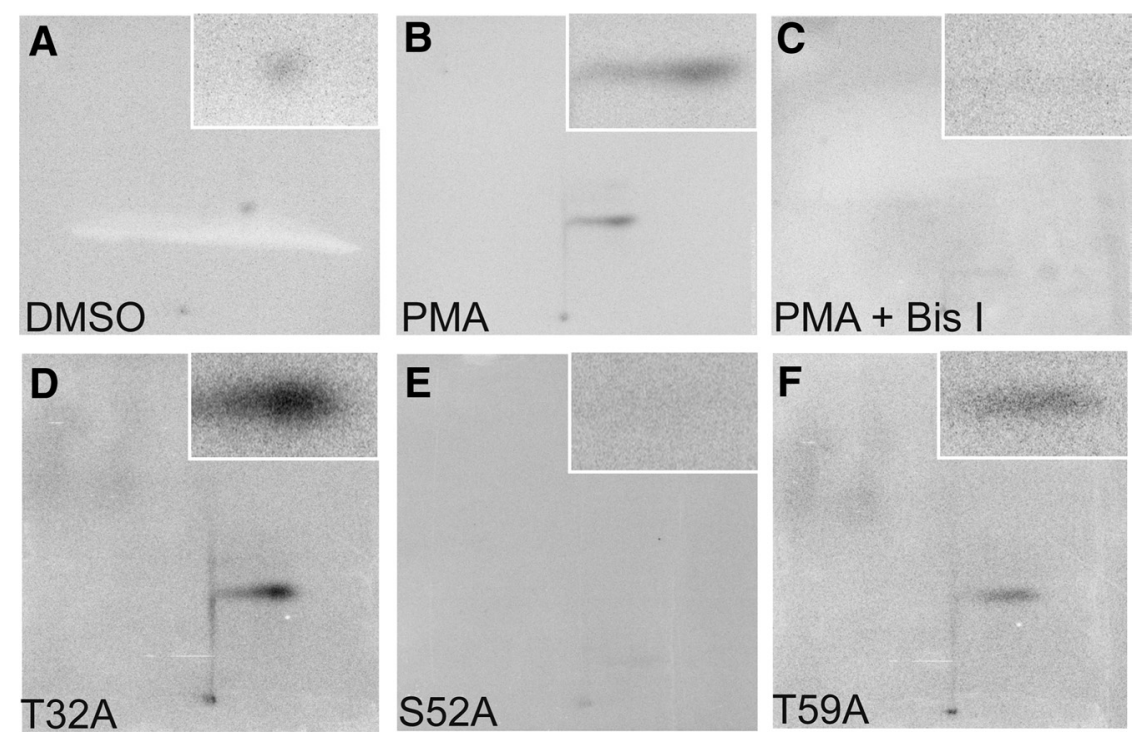

Figure 4. Rat SN1 is selectively phosphorylated at the 552 residue. COS-7 cells transiently transfected with wild-type or mutant SN1 were incubated with [ ${ }^{32} \mathrm{P}$ ] orthophosphate and DMSO or PMA, with or without Bis I, for $30 \mathrm{~min}$, followed by immunopurification of SN1 and phosphopeptide mapping as described in the legend to Figure 3. $A$, A weakly labeled phosphopeptide is detected when cells transfected with rat wtSN1 are incubated with vehicle (DMSO). $\boldsymbol{B}$, In the presence of $1 \mu \mathrm{MPMA}$, a phosphopeptide with much stronger labeling is detected. C, Coapplication of $100 \mathrm{~nm}$ Bis I with PMA abolishes labeling of the phosphopeptide. D, F, Cells transfected with T32A-SN1 (D) or T59A-SN1 $(\boldsymbol{F})$ mutants and stimulated with PMA also reveal a phosphorylated peptide. $\boldsymbol{E}$, No phosphopeptide is detected during stimulation with PMA when cells are transfected with S52A-SN1 mutant. Insets show the same site at higher magnification with or without a radioactive spot representing phosphorylated SN1 peptide.

ylation site (supplemental Table S1, available at www.jneurosci.org as supplemental material). Thus, SN1 has several putative phosphorylation sites, and two different computer-based analysis programs point to S52 as a potential PKC target. 
Under control conditions, PS120 cells stably expressing SN1 or COS-7 cells transiently expressing SN1 showed pronounced immunostaining for $\mathrm{SN} 1$ on the plasma membrane [Fig. $2 \mathrm{~A}, \mathrm{C}$ and supplemental Fig. S2 A (available at www.jneurosci.org as supplemental material), respectively]. $\mathrm{SN} 1$ is colocalized with the cell membrane marker WGA (Fig. $2 A$ ), which selectively binds to sugar residues enriched in the cell membrane. Activation of PKC by PMA results in trafficking of SN1 from the cell membrane to intracellular compartments (Fig. $2 B, D$ ) (supplemental Fig. S2 $B$, available at www.jneurosci.org as supplemental material). In particular, SN1 becomes partly colocalized with syntaxin 6 , a marker of the trans-Golgi network (TGN), during activation of PKC (Fig. 2C,D).

Internalization of SN1 during activation of $\mathrm{PKC}$ was further supported by Western blotting. After PMA stimulation, cells were biotinylated at $4^{\circ} \mathrm{C}$ (to prevent additional internalization), followed by avidin pull-down to separate cell surface proteins from proteins residing in intracellular compartments (intracellular proteins). SDS-PAGE of the biotinylated membrane fraction demonstrates that PKC activation leads to reduced plasma membrane immunostaining for SN1 in a time-dependent manner in two different cell lines: transiently transfected COS-7 cells (supplemental Fig. S2C, available at www.jneurosci.org as supplemental material) and stably transfected PS120 cells (Fig. 2E). We also quantified the reduction in immunostaining for SN1 in PS120 cells. Surface SN1 immunoreactivity is reduced by $\sim 50 \%$ after $0.5 \mathrm{~h}$ and stays low for the next $2 \mathrm{~h}$. However, after $5 \mathrm{~h}$, the plasma membranes regained some immunoreactivity for SN1 (Fig. 2F). Addition of cycloheximide, a protein synthesis inhibitor, only partly inhibits the reappearance of $\mathrm{SN} 1$ in the plasma membrane (data not shown). In the presence of Bis I, an inhibitor of PKC activity, PMA stimulation results in no significant reduction of surface SN1 levels (Fig. $2 E)(79.9 \pm 10.9 \%$ after $5 \mathrm{~h}$ ). Altogether, our data suggest that PMA activation of PKC alters localization of SN1.

\section{Phosphorylation of the $\mathrm{N}$ terminal of rat $\mathrm{SN} 1$ in vitro}

We hypothesized that, if the reduced surface expression of SN1 during PKC activation is a consequence of SN1 phosphorylation, the most likely candidates for this are the putative phosphorylation sites on the $\mathrm{N}$ terminal of the protein. This is because terminal parts of transporters and other membrane proteins are often key elements in protein regulation (Wang et al., 2003). A GSTfusion protein containing the $\mathrm{N}$-terminal amino acid sequence of SN1 (N-SN1-GST fusion protein) was therefore incubated with catalytic subunit of rat brain PKC in the presence of $\left[\gamma_{-}{ }^{32} \mathrm{P}\right]$ ATP. Analysis by SDS-PAGE and phosphopeptide mapping demonstrate robust phosphorylation of one major peptide (Fig. 3A). To identify the specific PKC isoforms involved, we repeated the experiment but now in the presence of recombinant classical PKC isoforms. PKC isoforms $\alpha$ and $\gamma$ were able to phosphorylate the N-SN1-GST fusion protein in vitro, whereas $\beta$ I and $\beta$ II did not induce detectable phosphorylation (Fig. $3 B-D$ ) (results not shown for $\beta$ II). Likewise, we tested the atypical PKCs $(\delta, \varepsilon, \eta, \theta$, and $\zeta$ ), which did not phosphorylate N-SN1-GST (data not shown). Furthermore, human CKII phosphorylated N-SN1-GST fusion protein in vitro but produced a different phosphorylated peptide (supplemental Fig. S3, available at www.jneurosci.org as supplemental material). Altogether, these data demonstrate direct phosphorylation of rat $\mathrm{SN} 1$ specifically by $\mathrm{PKC} \alpha$ and $\mathrm{PKC} \gamma$ in vitro.
A

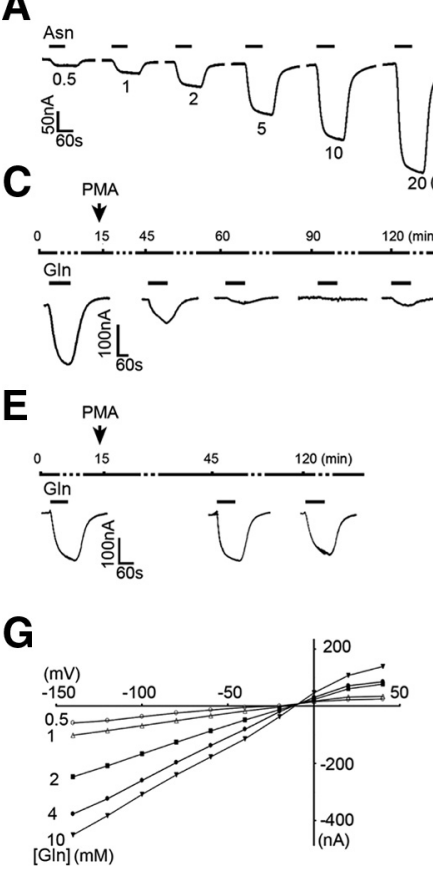

B
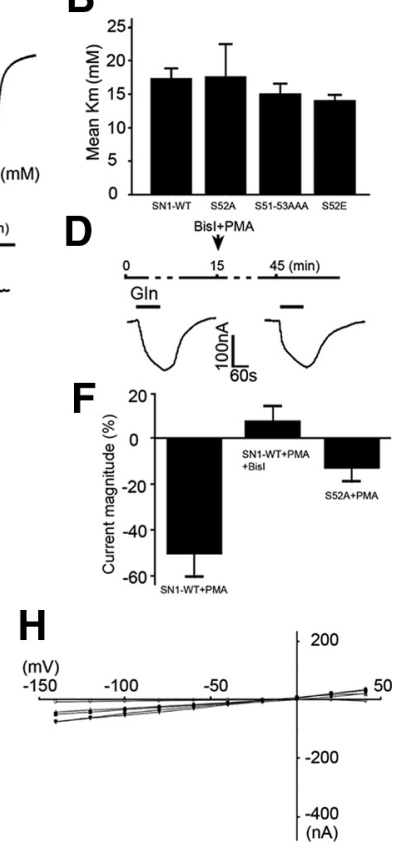

Figure 5. PMA-induced phosphorylation of $S \mathrm{~N} 1$ at $S 52$ reduces $V_{\max }$ but has no effect on $K_{\mathrm{m}}$. Wild-type and mutant SN1 were expressed in X. laevis oocytes, and their electrophysiological properties were characterized by TEVC. $A$, Application of asparagine (Asn) at increasing concentrations to oocytes expressing S52A mutant induced increasing inward currents. $B$, Oocytes expressing wild-type SN1 (SN1-WT) or three mutant (S52A, SSS51-53AAA, S52E) were incubated with different concentrations of asparagine, and the $K_{\mathrm{m}}$ was calculated at $-60 \mathrm{mV}$. There are no significant changes in $K_{\mathrm{m}}$ between wtSN1 and the mutants. $C$, Oocytes expressing wildtype SN1 were stimulated with PMA for $15 \mathrm{~min}$, and glutamine-induced currents were measured before, during, and at different time points after stimulation. Note the gradual reduction in the current magnitude and some recovery after $120 \mathrm{~min}$. $\boldsymbol{D}$, The effect of PMA on glutamineinduced currents in oocytes expressing wild-type SN1 is suppressed when coapplied with Bis I. $\boldsymbol{E}$, No significant effects were seen on the magnitude of glutamine-induced currents during stimulation with PMA in oocytes expressing S52A-SN1 mutant. $F$, Quantification of the relative changes seen in current magnitude during incubation with glutamine before and after PMA stimulation. Note the reduction in inward currents seen in wild-type SN1 and lack of reduction when Bis $\mathrm{l}$ is added to the incubation buffer. The S52A-SN1 mutant shows insignificant changes in current magnitude during PMA stimulation. $\mathbf{G}, \boldsymbol{H}$, Current-voltage relationship during increasing concentrations of glutamine is shown in a representative oocyte expressing wtSN1 before $(\boldsymbol{G})$ and after $(\boldsymbol{H})$ PMA stimulation. Note a dramatic reduction in the inducible current at all potentials after PMA stimulation. Glutamine (GIn) at $2 \mathrm{~mm}$ was applied in $\mathbf{C}-\boldsymbol{H}$. Bis I at $100 \mathrm{~nm}$ and $1 \mu \mathrm{M}$ PMA were applied in all cases.

\section{Identification of the phosphorylation site with site-directed mutagenesis of SN1}

Although N-SN1-GST fusion protein is phosphorylated in vitro, the observed trafficking of $\mathrm{SN} 1$ in cell cultures could be indirectly attributable to PKC-mediated phosphorylation of an interacting protein regulating trafficking of SN1. We therefore labeled SN1expressing COS-7 cells and PS120 cells with $\left[{ }^{32} \mathrm{P}\right]$ orthophosphate, followed by stimulation with PMA only, PMA together with Bis I, or the vehicle only (DMSO). After cell lysis, immunoprecipitation, SDS-PAGE, and thermolytic phosphopeptide mapping, stimulation with PMA generated a single phosphopeptide in both cell types, supporting that $\mathrm{SN} 1$ protein can also be directly phosphorylated within cellular context (Fig. 4B) (supplemental Fig. $S 4 B$, available at www.jneurosci.org as supplemental material). Incubation with a vehicle (DMSO) or inhibition of $\mathrm{PKC}$ with the protein kinase inhibitor staurosporine $(100 \mathrm{~nm})$ or the PKC-specific inhibitor Bis I inhibited these changes, bolstering a role for PKC in the phosphorylation of 
SN1 in intact cells (Fig. 4A,C) (supplemental Fig. S4A,C) (results not shown for staurosporine). Importantly, the data demonstrate phosphorylation of one single thermolytic peptide from $\mathrm{SN} 1$ in intact cells.

The target residue(s) for the classical PKC isoforms were identified by inducing single amino acid mutations at the putative phosphorylation sites in rat $\mathrm{N}$-terminal SN1. Thus, the T32, S52, T59, S51, S53, and SSS51-53 residues of SN1 were mutated to alanine, a residue that cannot be phosphorylated. The generated mutants were expressed in COS-7 cells and labeled with $\left[{ }^{32} \mathrm{P}\right]$ orthophosphate, followed by PMA stimulation. Only the triple mutant SSS51-53AAA and the S52A resisted phosphorylation, whereas all the other mutants were phosphorylated in the same way as wild-type (wt) SN1 protein (results from three mutants shown in Fig. $4 D-F$ ). Hence, our data indicate that the $\mathrm{S} 52$ residue is selectively targeted by PKC and that no other sites are phosphorylated by PKC under these conditions (although we cannot exclude that S52 controls phosphorylation of other residues). In contrast, CKII phosphorylates T59 of rat $\mathrm{SN} 1$ as confirmed by mass spectroscopy (data not shown), consistent with a different phosphopeptide (supplemental Fig. S3, available at www.jneurosci.org as supplemental material).

\section{Electrophysiological characterization of SN1 phosphorylation in $X$. laevis oocytes}

To investigate the functional implications of phosphorylation, phosphosite mutants of rat $\mathrm{SN} 1$ were generated and characterized in X. laevis oocytes: after injection of in vitro-transcribed mRNA into oocytes, SN1 transport properties were studied using TEVC technique. Oocytes expressing S52A-SN1 and perfused with asparagine or glutamine showed substrate-dependent inward currents with typical system $\mathrm{N}$ characteristics (results for asparagine shown in Fig. 5A) as reported for wtSN1 (Chaudhry et al., 2001). At steady-state conditions, wtSN1 responded to glutamine with large inward currents. However, during PMA treatment of the same oocytes, glutamine-induced $(2 \mathrm{mM})$ inward currents were dramatically reduced and almost abolished after $\sim 90 \mathrm{~min}$, although some activity was regained after $120 \mathrm{~min}$ (Fig. $5 C, F)$. This effect must be attributable to phosphorylation at $\mathrm{S} 52$ because oocytes expressing the S52A mutant did not respond to PMA stimulation with a reduction in glutamine-induced inward currents even after $120 \mathrm{~min}$ (Fig. 5E,F). Support for a PKCmediated effect is also provided by the lack of reduction in the response to glutamine at stimulation of oocytes with PMA in the presence of Bis I (Fig. 5D,F).

The reduction in glutamine-induced currents during PKC activation could be attributable to phosphorylation of S52 affecting the affinity of the transporter toward the substrate or a redistribution of the protein from the cell membrane. No significant change was seen in $K_{\mathrm{m}}$ for asparagine in oocytes expressing wtSN1 or the three mutants SSS51-53AAA, S52A, or S52E (Fig. 5B). The first two mutants resemble unphosphorylated forms, whereas S52E mimics a constitutively phosphorylated form. These data rule out any effects of phosphorylation on substrate binding. The current-voltage relationship was then investigated in oocytes expressing wtSN1. Currents were measured under voltage jumps from -140 to $+40 \mathrm{mV}$ in $20 \mathrm{mV}$ increments during stimulation with different concentrations of glutamine. Large inward currents are seen at hyperpolarized conditions, which increase with increasing concentrations of glutamine (Fig. 5G). At depolarized conditions, outward currents are increased in response to increasing glutamine concentrations. The reversal potential does not change, confirming that the currents are attributable to a substrate-induced channel activity associated with SN1 (Chaudhry et al., 2001). Current-voltage relationships of the same wtSN1-expressing oocytes were investigated after stimulation with PMA (Fig. $5 H$ ). There is a dramatic effect on the induced current at all potentials and no effect on the reversal potential. Indeed, $V_{\max }$ reduction is significant at -120 and $-60 \mathrm{mV}\left(p<0.01\right.$ in both cases), whereas $K_{\mathrm{m}}$ at the same potentials shows no significant changes (supplemental Fig. S5, available at www.jneurosci.org as supplemental material) $(p>0.05)$. Altogether, these results are consistent with a reduction in the number of functional transporters on the cell membranes and indicate phosphorylation-induced internalization of the protein.

\section{SN1 phosphorylated at S52 is sequestered}

We hypothesized that, if phosphorylation occurs at S52 and stimulates internalization, we would find intracellular reservoirs of phosphorylated SN1 (P-SN1) after PMA stimulation. We therefore generated antibodies that selectively recognize SN1 phosphorylated at S52. Rabbits were immunized with peptides from the SN1 N terminus in which S52 was modified with a phosphate group. After purification of serum on a phosphopeptide column and a column with the nonphosphorylated peptide, antibodies were obtained that recognize only SN1 phosphorylated on S52 and not the unphosphorylated protein (data not shown). Western immunoblotting of unstimulated PS120 cells expressing SN1 showed barely any staining for phosphorylated SN1 (Fig. 6A, lane 
1). Addition of PMA to stimulate phosphorylation of SN1 leads to significantly more phosphorylation after $30 \mathrm{~min}$ (Fig. 6 A, lane 2 ). However, the amount of protein that is phosphorylated at a given time is small, reflecting the dynamic nature of this process, which is readily reversed by a number of protein phosphatases. Inhibition of protein phosphatases should therefore increase phosphorylation of SN1. Indeed, in the presence of okadaic acid $(0.5 \mu \mathrm{M})$, the amount of phosphorylated SN1 increases dramatically (Fig. 6A, lane 3 ).

Finally, we wanted to demonstrate changes in the subcellular localization of the unphosphorylated (SN1) and P-SN1 during PMA activation. Stably transfected PS120 cells were double stained by antibodies specifically recognizing unphosphorylated SN1 or phosphorylated SN1. The staining by the phosphospecific antibodies was generally very weak, reflecting the low levels of SN1 phosphorylated in unstimulated cells (Fig. 6D). In contrast, pronounced staining was obtained on the plasma membranes for unphosphorylated SN1 in the same cells (Fig. 6D). However, stimulation with PMA (Fig. 6E) and/or the phosphatase inhibitor okadaic acid (data not shown) demonstrated increased intracellular staining for phosphorylated $\mathrm{SN} 1$, whereas the plasma membranes remained unstained, further supporting the notion that phosphorylated SN1 resides in intracellular compartments. Concomitantly, the staining for the unphosphorylated $\mathrm{SN} 1$ was reduced in the plasma membrane (Fig. 6E). PMA-induced intracellular staining for P-SN1 was reduced in the presence of Bis I, whereas SN1 staining at the plasma membrane was maintained (Fig. 6 F). Finally, we investigated whether the endogenous SN1 in astroglial cells could be phosphorylated and whether this also resulted in altered subcellular localization. Stimulation of primary cultures of rat brain astrocytes with PMA increased intracellular levels of phosphorylated SN1 at S52 as recognized by the phospho-specific SN1 antibody (Fig. 6B, C), further bolstering a role of phosphorylation in SN1 trafficking (see Fig. 8). No surface staining was seen for P-SN1 in astroglial cells.

\section{Prolonged activation of PKC results in degradation of SN1}

Several transporters are degraded after retrieval from the plasma membrane (Daniels and Amara, 1999; Susarla and Robinson, 2008). We therefore investigated whether the PKC-mediated internalization of SN1 is followed by degradation of the protein. Lysates of PS120 cells stably expressing SN1 and stimulated with PMA were immunoblotted for SN1. A broad band close to 50 $\mathrm{kDa}$, resembling the reported band for SN1 in brain, kidney, and pancreas tissue (Boulland et al., 2002, 2003; Solbu et al., 2005; Gammelsaeter et al., 2009), was seen before PMA stimulation. A time course of PMA stimulation shows a gradual reduction in the staining of this band and the simultaneous appearance of a broad band of $\sim 40 \mathrm{kDa}$, which probably represents degraded SN1 (Fig. $7 A, B$ ). These changes are sensitive to the presence of Bis I (Fig. $7 A, B)$, again supporting that they are partly attributable to PKC activation. These data are further bolstered by avidin pull-down and quantification of nonbiotinylated intracellular proteins. If SN1 translocation was fully reversible, the content of intact protein in the intracellular fraction would be increased. The observed decrease in intact rat SN1 protein with $\mathrm{PKC}$ activation, together with the intracellular accumulation of degradation products (data not shown), suggest that some of the protein is degraded. Bis I partly inhibits this process (data not shown).
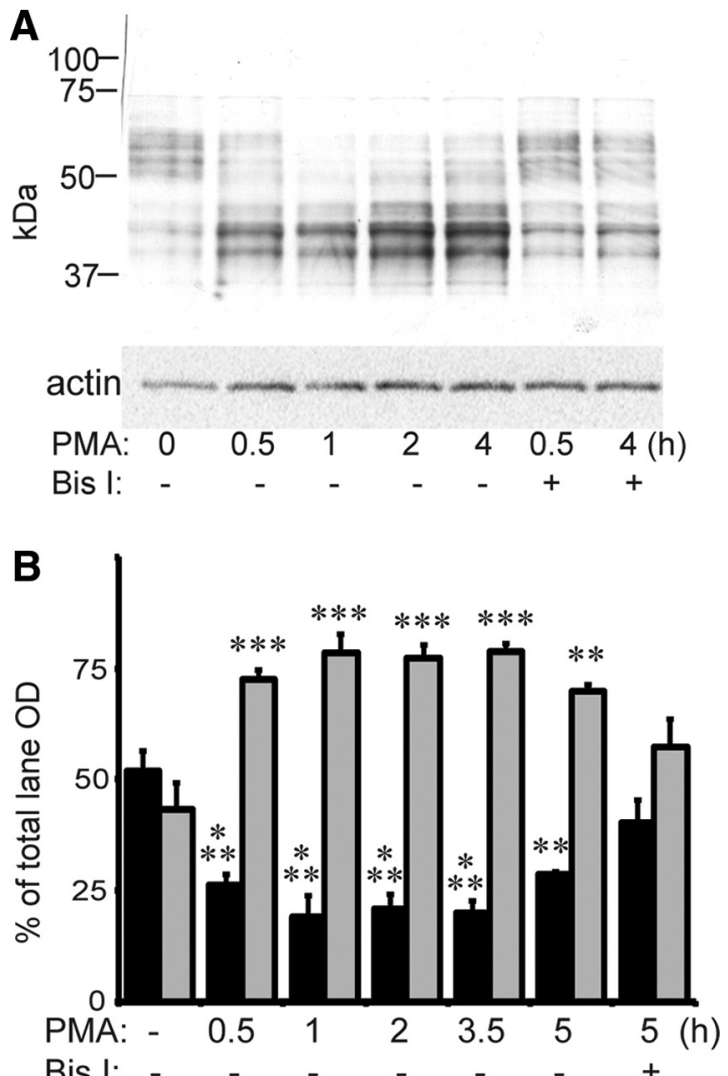

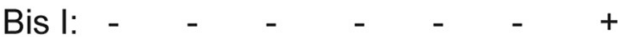

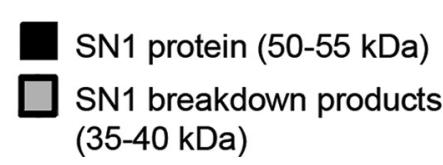

Figure 7. Prolonged PMA stimulation leads to degradation of SN1. $A$, Representative Western immunoblot showing lysates of PS120 cells stably transfected for SN1 and treated with $1 \mu \mathrm{m}$ PMA with or without $100 \mathrm{~nm}$ Bis I for the times indicated, followed by immunoblotting with affinity-purified anti-SN1. Bottom shows the same blot treated with anti-actin as a loading control. $\boldsymbol{B}$, Lysate blots were analyzed by quantitative Western blotting and presented as percentage of total density in each lane. There is a significant reduction in the higher-molecularweight band, whereas the lower-molecular-weight band increases simultaneously. ${ }^{* *} p<$ $0.01,{ }^{* * *} p<0.001$, when analyzed with SPSS (mixed models). Black columns, SN1 immunoreactivity at $\sim 50-55 \mathrm{kDa}$; gray columns, SN1 immunoreactivity at $\sim 35-40 \mathrm{kDa}$. The bar graphs show mean \pm SEM of results from three to six experiments.

\section{Discussion}

The results show that PKC $\alpha$ and PKC $\gamma$ specifically and independently phosphorylate rat $\mathrm{SN} 1$ at residue S52 both in vitro and in intact cells. PMA-induced activation of PKC and subsequent phosphorylation of SN1 heterologously expressed in X. laevis oocytes results in a dramatic reduction in $V_{\max }$, whereas no significant changes were observed for $K_{\mathrm{m}}$. In mammalian cells, including astroglia, PMA-induced phosphorylation of SN1 stimulates its targeting to intracellular reservoirs. However, prolonged stimulation of PKC by PMA results in degradation of SN1. When coapplied with Bis I, PMA fails to stimulate PKC phosphorylation of SN1, and SN1 degradation is hampered. Interestingly, mutation of other putative phosphorylation sites, including the flanking serines S51 and S53, has no effect on SN1 phosphorylation or on its kinetic properties and trafficking, thereby excluding involvement of these residues in the PKC-mediated phosphorylation event. Using the structure of two members of the amino acid/polyamine/ organocation family of bacterial amino acid transporters (Gao et 
al., 2009; Shaffer et al., 2009) as templates, we have modeled a putative threedimensional structure for SN1 that suggests that S52 is openly exposed on the protein surface (supplemental Fig. S1B, available at www.jneurosci.org as supplemental material). Altogether, our data identify S52 of rat SN1 as a key target for $\mathrm{PKC} \alpha$ and $\mathrm{PKC} \gamma$ phosphorylation and for the dynamic regulation of rat $\mathrm{SN} 1$ activity at the plasma membrane.

\section{Membrane trafficking of many neurotransmitter transporters is regulated by phosphorylation at specific sites}

Our demonstration of SN1 trafficking agrees with reports showing dynamic recycling of membrane proteins between plasma membrane and intracellular compartments (Sorkin and Von Zastrow, 2002). Regulation of the levels of NMDA and AMPA receptors on the plasma membrane and their clustering at the synapses is a prerequisite for their involvement in the induction of long-term potentiation and long-term depression, and such trafficking is governed partly by PKCmediated phosphorylation at specific sites (Scannevin and Huganir, 2000; Newpher and Ehlers, 2008). In the same way, most transporter proteins are also prone to phosphorylation at specific sites by PKC, and this regulates the number of proteins residing on the plasma membrane and their activity (Robinson, 2002; Wang et al., 2003; Melikian, 2004).

$\mathrm{SN} 1$ belongs to a growing family of transporters that includes system A and system N transporters (Chaudhry et al., 2002a; Sundberg et al., 2008). A hallmark of these two systems is that they are subject to extensive adaptive, hormonal, and osmotic regulation (Collarini and Oxender, 1987; Palacín et al., 1998). A nutrition signaling cascade that includes activation of phosphatidylinositol 3-kinase (PI3K) and mammalian target of rapamycin (mTOR) has been shown to be important for induction of system A and system L activities (Peyrollier et al., 2000; Liu et al., 2004). In hepatocytes, insulin regulates expression of SN1 through the PI3KmTor signaling cascade ( $\mathrm{Gu}$ et al., 2005). Other studies show that PKC activation directly increases cellular amino acid uptake in general (Dawson and Cook, 1987; Karl, 1995). However, the molecular mechanisms involved have been elusive. We now reveal the specific PKC-mediated phosphorylation site on rat SN1 and demonstrate that only the PKC $\alpha$ and PKC $\gamma$ isoforms are involved. These isoforms are active in brain tissue, glioma cells, hepatocytes, pancreatic B-cells, kidney cells, and skeletal muscle cells (Huang et al., 1988; Croquet et al., 1996; Tian et al., 1996; Pfaff et al., 1999; Sneddon et al., 2000; Acevedo-Duncan et al., 2004; Gonzalez et al., 2005). The same cells also express SN1 (Boulland et al., 2002; Gu et al., 2005; Onan et al., 2005; Solbu et al., 2005; Gammelsaeter et al., 2009). Indeed, intracellular SN1-stained vesicle-like structures have been demonstrated in glial and kidney tubular cells, underpinning SN1 trafficking (Boulland et al., 2003; Solbu et al., 2005). Because PKC $\alpha$ and $\mathrm{PKC} \gamma$ isoforms participate in different signaling cascades at dif- ferent conditions, our data suggest differential cell-specific regulation of SN1 activity by phosphorylation or dephosphorylation at a variety of physiological and pathological conditions.

\section{Functional implications of SN1 phosphorylation}

Sequestration of several neurotransmitter transporters as a consequence of PKC-mediated phosphorylation has been demonstrated, including transporters for dopamine (DAT), serotonin (SERT), noradrenalin (NET), and glycine (GLYT1b). This has functional impacts on recycling of the neurotransmitters (Sato et al., 1995; Melikian and Buckley, 1999; Ramamoorthy and Blakely, 1999; Jayanthi et al., 2005). The prevailing hypothesis on recycling of GABA and glutamate through the glutamate/GABAglutamine cycle proposes uptake of these transmitters into glial cells and subsequent conversion to glutamine before its release. Such cycling requires functional integrity of GABA and glutamate transporters on perisynaptic glial processes as well as the system $\mathrm{N}$ transporters $\mathrm{SN} 1$ and $\mathrm{SN} 2$, with the ability to release glutamine (Chaudhry et al., 2008). We now demonstrate that SN1 after its retrieval from the plasma membrane is targeted to the intracellular stores in which some of it may be colocalized with the TGN marker syntaxin 6. A reserve pool of the homologous system A transporters SAT1 and SAT2, acting on the neuronal membranes, is also colocalized with syntaxin 6 and shown to be recruited to the plasma membranes during hormonal stimulation (Hatanaka et al., 2006; Solbu et al., 2010). 
Several reports support functional coupling between glial glutamate transporters and SN1 whereby activation of glutamate transporters with subsequent increase in intracellular concentrations of $\mathrm{Na}^{+}$and glutamate favors the release mode of SN1 (Bröer et al., 2004). Our data now reveal interesting similarities between SN1 regulation and mechanisms involved in the regulation of the glial glutamate transporter GLT and glutamate-aspartate transporter GLAST: PMA-induced activation of PKC also stimulates internalization of the glial glutamate transporters GLT and GLAST (Kalandadze et al., 2002; Vanoni et al., 2004; Guillet et al., 2005). Furthermore, coimmunoprecipitation of GLT and PKC $\alpha$ has been demonstrated (Gonzalez et al., 2005). In addition, the glial GLT and GLAST are specifically targeted to small glial processes in the vicinity of synapses, and in the same processes, SN1 is also specifically enriched (Chaudhry et al., 1995; Boulland et al., 2002). Our current data show that prolonged PMA-induced stimulation results in degradation of SN1, and the time course coincides with the demonstrated internalization and subsequent degeneration of GLT (Susarla and Robinson, 2008). Thus, the glial glutamate and glutamine transporters may be targeted by similar regulatory mechanisms as a response to certain synaptic activity synergistically inhibiting glutamate recycling. Indeed, glial cells are enriched with G-protein-coupled receptors, and their activation by glutamate, GABA, or other neurotransmitters are important endogenous triggers of PKC activation (Beckman et al., 1999). Complementary expression of both system $\mathrm{A}$ and non-system A transporters has been demonstrated on neurons, and it has been shown that the availability of glutamine regulates generation of the fast neurotransmitters (Rae et al., 2003; Jenstad et al., 2009; Solbu et al., 2010; Tani et al., 2010) and shapes the quantal size (Armano et al., 2002; Liang et al., 2006; Fricke et al., 2007). Thus, SN1 may represent a key target for regulation of the glutamate/GABA-glutamine cycle (Fig. 8). Such regulation may therefore have a profound impact on synaptic plasticity.

\section{Species-specific differences in the phosphorylation of SN1}

We have demonstrated selective phosphorylation of S52 of rat SN1 and shown that phosphorylation of this residue is sufficient for PKC-induced internalization. However, S52 only occurs in rat and sheep SN1 (Fig. 1B) (supplemental Fig. S1 $A$, available at www.jneurosci.org as supplemental material). All other species, including human and mice, have a conserved proline at this position. Interestingly, similar species differences in phosphorylation sites exist for other proteins as well. The rat Na,K-ATPase includes two putative phosphorylation sites: S11 and S18. The human, mouse, and pig orthologs have S11 but not S18. Dopamine induces internalization of rat $\mathrm{Na}, \mathrm{K}-\mathrm{ATPase}$ by PKCmediated phosphorylation at S18. In human, mouse, and pig, dopamine achieves the same effect by stimulating phosphorylation of S11 (Efendiev and Pedemonte, 2006). S51 and S53 of SN1 are conserved in all species analyzed. In addition, some species, but not rat and sheep, have additional serines and threonines upstream and downstream of S52. Thus, SN1 in human, mouse, and other species may be regulated by alternative phosphorylation of one of these sites. Our computer analyses point to S53 as a potential PKC phosphorylation site in the absence of S52 (supplemental Table S1, available at www.jneurosci.org as supplemental material). Indeed, in preliminary experiments, $\mathrm{PKC}$ also phosphorylated the N-terminal mouse SN1-GST fusion protein in vitro, and a phosphopeptide was revealed with similar charge but a larger molecular weight (data not shown).

\section{Conclusion}

PKC has been implicated in the regulation of a variety of cellular functions through phosphorylation of specific serine and threonine residues of cellular proteins. The different PKC isoforms yield specificity in time and space and convey divergence in signaling cascades. SN1 is involved in transmitter generation and nitrogen metabolism and shows a highly differential cellular and subcellular localization (Chaudhry et al., 1999; Boulland et al., 2002; Gammelsaeter et al., 2009). Together with the previously demonstrated regulation of SN1 at protein and mRNA level (Chaudhry et al., 2001; Solbu et al., 2005), the current demonstration of phosphorylation of rat $\mathrm{SN} 1$ by two $\mathrm{PKC}$ isoforms targeting a single residue in the $\mathrm{N}$ terminal adds a new dimension to the complex regulation of SN1. Dysregulation of membrane trafficking of SN1 may result in altered synaptic transmission or in pathology, and this novel mechanistic insight may represent a potential target for novel therapeutic approaches in the future.

\section{References}

Acevedo-Duncan M, Russell C, Patel S, Patel R (2004) Aloe-emodin modulates PKC isozymes, inhibits proliferation, and induces apoptosis in U-373MG glioma cells. Int Immunopharmacol 4:1775-1784.

Albrecht J, Sonnewald U, Waagepetersen HS, Schousboe A (2007) Glutamine in the central nervous system: function and dysfunction. Front Biosci 12:332-343.

Armano S, Coco S, Bacci A, Pravettoni E, Schenk U, Verderio C, Varoqui H, Erickson JD, Matteoli M (2002) Localization and functional relevance of system a neutral amino acid transporters in cultured hippocampal neurons. J Biol Chem 277:10467-10473.

Bacci A, Sancini G, Verderio C, Armano S, Pravettoni E, Fesce R, Franceschetti S, Matteoli M (2002) Block of glutamate-glutamine cycle between astrocytes and neurons inhibits epileptiform activity in hippocampus. J Neurophysiol 88:2302-2310.

Battaglioli G, Martin DL (1990) Stimulation of synaptosomal gammaaminobutyric acid synthesis by glutamate and glutamine. J Neurochem 54:1179-1187.

Beckman ML, Bernstein EM, Quick MW (1999) Multiple G proteincoupled receptors initiate protein kinase $\mathrm{C}$ redistribution of GABA transporters in hippocampal neurons. J Neurosci 19:RC9(1-6).

Boulland JL, Osen KK, Levy LM, Danbolt NC, Edwards RH, Storm-Mathisen J, Chaudhry FA (2002) Cell-specific expression of the glutamine transporter SN1 suggests differences in dependence on the glutamine cycle. Eur J Neurosci 15:1615-1631.

Boulland JL, Rafiki A, Levy LM, Storm-Mathisen J, Chaudhry FA (2003) Highly differential expression of SN1, a bidirectional glutamine transporter, in astroglia and endothelium in the developing rat brain. Glia 41:260-275.

Boulland JL, Qureshi T, Seal RP, Rafiki A, Gundersen V, Bergersen LH, Fremeau RT Jr, Edwards RH, Storm-Mathisen J, Chaudhry FA (2004) Expression of the vesicular glutamate transporters during development indicates the widespread corelease of multiple neurotransmitters. J Comp Neurol 480:264-280.

Bröer A, Deitmer JW, Bröer S (2004) Astroglial glutamine transport by system $\mathrm{N}$ is upregulated by glutamate. Glia 48:298-310.

Chaudhry FA, Lehre KP, van Lookeren Campagne M, Ottersen OP, Danbolt NC, Storm-Mathisen J (1995) Glutamate transporters in glial plasma membranes: highly differentiated localizations revealed by quantitative ultrastructural immunocytochemistry. Neuron 15:711-720.

Chaudhry FA, Reimer RJ, Krizaj D, Barber D, Storm-Mathisen J, Copenhagen DR, Edwards RH (1999) Molecular analysis of System N suggests novel physiological roles in nitrogen metabolism and synaptic transmission. Cell 99:769-780.

Chaudhry FA, Krizaj D, Larsson P, Reimer RJ, Wreden C, Storm-Mathisen J, Copenhagen D, Kavanaugh M, Edwards RH (2001) Coupled and uncoupled proton movement regulates amino acid transport by System N. EMBO J 20:7041-7051.

Chaudhry FA, Reimer RJ, Edwards RH (2002a) The glutamine commute: take the N line and transfer to the A. J Cell Biol 157:349-355.

Chaudhry FA, Schmitz D, Reimer RJ, Larsson P, Gray AT, Nicoll R, Ka- 
vanaugh M, Edwards RH (2002b) Glutamine uptake by neurons: interaction of protons with system a transporters. J Neurosci 22:62-72.

Chaudhry FA, Boulland JL, Jenstad M, Bredahl MK, Edwards RH (2008) Pharmacology of neurotransmitter transport into secretory vesicles. Handb Exp Pharmacol 77-106.

Collarini EJ, Oxender DL (1987) Mechanisms of transport of amino acids across membranes. Annu Rev Nutr 7:75-90.

Croquet F, Bréhier A, Gil S, Davy J, Féger J (1996) Five isoenzymes of protein kinase $\mathrm{C}$ are expressed in normal and STZ-diabetic rat hepatocytes: effect of phorbol 12-myristate 13-acetate. Biochim Biophys Acta 1315:163-168.

Danbolt NC (2001) Glutamate uptake. Prog Neurobiol 65:1-105.

Daniels GM, Amara SG (1999) Regulated trafficking of the human dopamine transporter. Clathrin-mediated internalization and lysosomal degradation in response to phorbol esters. J Biol Chem 274:35794-35801.

Dawson WD, Cook JS (1987) Parallel changes in amino acid transport and protein kinase C localization in LLC-PK1 cells treated with TPA or diradylglycerols. J Cell Physiol 132:104-110.

Efendiev R, Pedemonte CH (2006) Contrary to rat-type, human-type Na,KATPase is phosphorylated at the same amino acid by hormones that produce opposite effects on enzyme activity. J Am Soc Nephrol 17:31-38.

Fricke MN, Jones-Davis DM, Mathews GC (2007) Glutamine uptake by System A transporters maintains neurotransmitter GABA synthesis and inhibitory synaptic transmission. J Neurochem 102:1895-1904.

Furness DN, Dehnes Y, Akhtar AQ, Rossi DJ, Hamann M, Grutle NJ, Gundersen V, Holmseth S, Lehre KP, Ullensvang K, Wojewodzic M, Zhou Y, Attwell D, Danbolt NC (2008) A quantitative assessment of glutamate uptake into hippocampal synaptic terminals and astrocytes: new insights into a neuronal role for excitatory amino acid transporter 2 (EAAT2). Neuroscience 157:80-94.

Gammelsaeter R, Jenstad M, Bredahl MK, Gundersen V, Chaudhry FA (2009) Complementary expression of SN1 and SAT2 in the islets of Langerhans suggests concerted action of glutamine transport in the regulation of insulin secretion. Biochem Biophys Res Commun 381:378-382.

Gao X, Lu F, Zhou L, Dang S, Sun L, Li X, Wang J, Shi Y (2009) Structure and mechanism of an amino acid antiporter. Science 324:1565-1568.

Gebhardt R, Kleemann E (1987) Hormonal regulation of amino acid transport system $\mathrm{N}$ in primary cultures of rat hepatocytes. Eur J Biochem 166:339-344.

González MI, Susarla BT, Robinson MB (2005) Evidence that protein kinase Calpha interacts with and regulates the glial glutamate transporter GLT-1. J Neurochem 94:1180-1188.

Gu S, Villegas CJ, Jiang JX (2005) Differential regulation of amino acid transporter SNAT3 by insulin in hepatocytes. J Biol Chem 280:26055-26062.

Guillet BA, Velly LJ, Canolle B, Masmejean FM, Nieoullon AL, Pisano P (2005) Differential regulation by protein kinases of activity and cell surface expression of glutamate transporters in neuron-enriched cultures. Neurochem Int 46:337-346.

Hatanaka T, Hatanaka Y, Tsuchida J, Ganapathy V, Setou M (2006) Amino acid transporter ATA2 is stored at the trans-Golgi network and released by insulin stimulus in adipocytes. J Biol Chem 281:39273-39284.

Haug LS, Jensen V, Hvalby O, Walaas SI, Ostvold AC (1999) Phosphorylation of the inositol 1,4,5-trisphosphate receptor by cyclic nucleotidedependent kinases in vitro and in rat cerebellar slices in situ. J Biol Chem 274:7467-7473.

Huang FL, Yoshida Y, Nakabayashi H, Young WS 3rd, Huang KP (1988) Immunocytochemical localization of protein kinase $\mathrm{C}$ isozymes in rat brain. J Neurosci 8:4734-4744.

Hundal HS, Rennie MJ, Watt PW (1987) Characteristics of L-glutamine transport in perfused rat skeletal muscle. J Physiol 393:283-305.

Jayanthi LD, Samuvel DJ, Blakely RD, Ramamoorthy S (2005) Evidence for biphasic effects of protein kinase $\mathrm{C}$ on serotonin transporter function, endocytosis, and phosphorylation. Mol Pharmacol 67:2077-2087.

Jenstad M, Quazi AZ, Zilberter M, Haglerød C, Berghuis P, Saddique N, Goiny M, Buntup D, Davanger S, Haug FMS, Barnes CA, McNaughton BL, Ottersen OP, Storm-Mathisen J, Harkany T, Chaudhry FA (2009) System A transporter SAT2 mediates replenishment of dendritic glutamate pools controlling retrograde signaling by glutamate. Cereb Cortex 19:1092-1106.

Kalandadze A, Wu Y, Robinson MB (2002) Protein kinase C activation decreases cell surface expression of the GLT-1 subtype of glutamate trans- porter. Requirement of a carboxyl-terminal domain and partial dependence on serine 486. J Biol Chem 277:45741-45750.

Karl PI (1995) Insulin-like growth factor-1 stimulates amino acid uptake by the cultured human placental trophoblast. J Cell Physiol 165:83-88.

Liang SL, Carlson GC, Coulter DA (2006) Dynamic regulation of synaptic GABA release by the glutamate-glutamine cycle in hippocampal area CA1. J Neurosci 26:8537-8548.

Ling R, Bridges CC, Sugawara M, Fujita T, Leibach FH, Prasad PD, Ganapathy $\mathrm{V}$ (2001) Involvement of transporter recruitment as well as gene expression in the substrate-induced adaptive regulation of amino acid transport system A. Biochim Biophys Acta 1512:15-21.

Liu XM, Reyna SV, Ensenat D, Peyton KJ, Wang H, Schafer AI, Durante W (2004) Platelet-derived growth factor stimulates LAT1 gene expression in vascular smooth muscle: role in cell growth. FASEB J 18:768-770.

Lohmann R, Souba WW, Zakrzewski K, Bode BP (1998) Stimulation of rat hepatic amino acid transport by burn injury. Metabolism 47:608-616.

McCarthy KD, de Vellis J (1980) Preparation of separate astroglial and oligodendroglial cell cultures from rat cerebral tissue. J Cell Biol 85:890-902.

Melikian HE (2004) Neurotransmitter transporter trafficking: endocytosis, recycling, and regulation. Pharmacol Ther 104:17-27.

Melikian HE, Buckley KM (1999) Membrane trafficking regulates the activity of the human dopamine transporter. J Neurosci 19:7699-7710.

Newpher TM, Ehlers MD (2008) Glutamate receptor dynamics in dendritic microdomains. Neuron 58:472-497.

Onan MC, Fisher JS, Ju JS, Fuchs BC, Bode BP (2005) Type I diabetes affects skeletal muscle glutamine uptake in a fiber-specific manner. Exp Biol Med (Maywood) 230:606-611.

O'Shea RD, Lau CL, Farso MC, Diwakarla S, Zagami CJ, Svendsen BB, Feeney SJ, Callaway JK, Jones NM, Pow DV, Danbolt NC, Jarrott B, Beart PM (2006) Effects of lipopolysaccharide on glial phenotype and activity of glutamate transporters: Evidence for delayed up-regulation and redistribution of GLT-1. Neurochem Int 48:604-610.

Palacín M, Estévez R, Bertran J, Zorzano A (1998) Molecular biology of mammalian plasma membrane amino acid transporters. Physiol Rev 78:969-1054.

Palii SS, Chen H, Kilberg MS (2004) Transcriptional control of the human sodium-coupled neutral amino acid transporter system A gene by amino acid availability is mediated by an intronic element. J Biol Chem 279:3463-3471.

Pastor-Anglada M, Dérijard B, Casado FJ (2005) Mechanisms implicated in the response of system a to hypertonic stress and amino acid deprivation still can be different. J Gen Physiol 125:41-42.

Peyrollier K, Hajduch E, Blair AS, Hyde R, Hundal HS (2000) L-leucine availability regulates phosphatidylinositol 3-kinase, p70 S6 kinase and glycogen synthase kinase-3 activity in L6 muscle cells: evidence for the involvement of the mammalian target of rapamycin (mTOR) pathway in the L-leucine-induced up-regulation of system A amino acid transport. Biochem J 350:361-368.

Pfaff IL, Wagner HJ, Vallon V (1999) Immunolocalization of protein kinase $\mathrm{C}$ isoenzymes alpha, betal and betaII in rat kidney. J Am Soc Nephrol 10:1861-1873.

Rae C, Hare N, Bubb WA, McEwan SR, Bröer A, McQuillan JA, Balcar VJ, Conigrave AD, Bröer S (2003) Inhibition of glutamine transport depletes glutamate and GABA neurotransmitter pools: further evidence for metabolic compartmentation. J Neurochem 85:503-514.

Ramamoorthy S, Blakely RD (1999) Phosphorylation and sequestration of serotonin transporters differentially modulated by psychostimulants. Science 285:763-766.

Robinson MB (2002) Regulated trafficking of neurotransmitter transporters: common notes but different melodies. J Neurochem 80:1-11.

Rodriguez P, Mitton B, Kranias EG (2005) Phosphorylation of glutathione$\mathrm{S}$-transferase by protein kinase C-alpha implications for affinity-tag purification. Biotechnol Lett 27:1869-1873.

Rothman DL, Behar KL, Hyder F, Shulman RG (2003) In vivo NMR studies of the glutamate neurotransmitter flux and neuroenergetics: implications for brain function. Annu Rev Physiol 65:401-427.

Sato K, Betz H, Schloss P (1995) The recombinant GABA transporter GAT1 is downregulated upon activation of protein kinase C. FEBS Lett 375:99-102.

Scannevin RH, Huganir RL (2000) Postsynaptic organization and regulation of excitatory synapses. Nat Rev Neurosci 1:133-141.

Shaffer PL, Goehring A, Shankaranarayanan A, Gouaux E (2009) Structure 
and mechanism of a $\mathrm{Na}^{+}$-independent amino acid transporter. Science 325:1010-1014.

Shotwell MA, Kilberg MS, Oxender DL (1983) The regulation of neutral amino acid transport in mammalian cells. Biochim Biophys Acta 737:267-284.

Sneddon AA, Delday MI, Maltin CA (2000) Amelioration of denervationinduced atrophy by clenbuterol is associated with increased PKC-alpha activity. Am J Physiol Endocrinol Metab 279:E188-E195.

Solbu TT, Boulland JL, Zahid W, Lyamouri Bredahl MK, Amiry-Moghaddam M, Storm-Mathisen J, Roberg BA, Chaudhry FA (2005) Induction and targeting of the glutamine transporter $\mathrm{SN} 1$ to the basolateral membranes of cortical kidney tubule cells during chronic metabolic acidosis suggest a role in $\mathrm{pH}$ regulation. J Am Soc Nephrol 16:869-877.

Solbu TT, Bjørkmo M, Berghuis P, Harkany T, Chaudhry FA (2010) SAT1, a glutamine transporter, is preferentially expressed in GABAergic neurons. Front Neuroanat 4:1.

Sorkin A, Von Zastrow M (2002) Signal transduction and endocytosis: close encounters of many kinds. Nat Rev Mol Cell Biol 3:600-614.

Sundberg BE, Wååg E, Jacobsson JA, Stephansson O, Rumaks J, Svirskis S, Alsiö J, Roman E, Ebendal T, Klusa V, Fredriksson R (2008) The evolu- tionary history and tissue mapping of amino acid transporters belonging to solute carrier families SLC32, SLC36, and SLC38. J Mol Neurosci 35:179-193.

Susarla BT, Robinson MB (2008) Internalization and degradation of the glutamate transporter GLT-1 in response to phorbol ester. Neurochem Int 52:709-722.

Tani H, Dulla CG, Huguenard JR, Reimer RJ (2010) Glutamine is required for persistent epileptiform activity in the disinhibited neocortical brain slice. J Neurosci 30:1288-1300.

Tian YM, Urquidi V, Ashcroft SJ (1996) Protein kinase C in beta-cells: expression of multiple isoforms and involvement in cholinergic stimulation of insulin secretion. Mol Cell Endocrinol 119:185-193.

Vanoni C, Massari S, Losa M, Carrega P, Perego C, Conforti L, Pietrini G (2004) Increased internalisation and degradation of GLT-1 glial glutamate transporter in a cell model for familial amyotrophic lateral sclerosis (ALS). J Cell Sci 117:5417-5426.

Wang D, Deken SL, Whitworth TL, Quick MW (2003) Syntaxin 1A inhibits GABA flux, efflux, and exchange mediated by the rat brain GABA transporter GAT1. Mol Pharmacol 64:905-913. 